DOI: $10.21767 / 2471-9803.1000147$

\title{
First Symptoms and Signs of Morbus Behcet
}

\section{Katarina I}

Obstetrics and Gynecology Department, Serbia

Corresponding author: Katarina I, Obstetrics and Gynecolgy, Serbia, Tel: +381-122-2267; E-mail: katarina_ikodinovic@hotmail.com Received date: February 14, 2017; Accepted date: February 16, 2017; Published date: February 26, 2017

Copyright: (C) 2017 Katarina I. This is an open-access article distributed under the terms of the Creative Commons Attribution License, which permits unrestricted use, distribution, and reproduction in any medium, provided the original author and source are credited.

Citation: Katarina I. First symptoms and signs of Morbus Behcet. Crit Care Obst Gyne. 2017, 3:1.

\section{Clinical Image}

In the year 2012, one 36 years old female presented with severe spontaneous pain in vagina and lesions on vulva. Macroscopic and under colposcopy I found white, solid, hard, round, painful and easy bleeding lesions on board with healthy tissue. Biopsy result was Mucosis manifestation of antibody reaction full of leukocyte, Papanikolau test then was III.

For 3-4 days pain and others symptoms disappeared without any treatment. I thought that it could be Linear IgA disease. After few months I took again Papanikolau test and was II.

3 years after this lesions in genital region, start to show up new lesions in mouth and esophagus with oral disorders. Lesions looks like aphta. They are often, painful, rounds. After exams, rheumatologist gave her another drug "Morbus Behcet". Her gynecological status now is in order Figure 1,2,3,4,5.

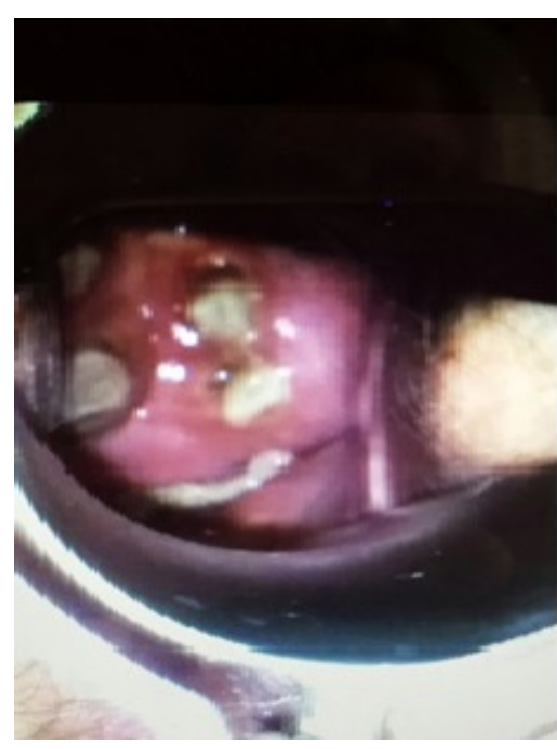

Figure 1 Macroscopic and under colposcopy found white, solid, hard, round, painful and easy bleeding lesions on board with healthy tissue.

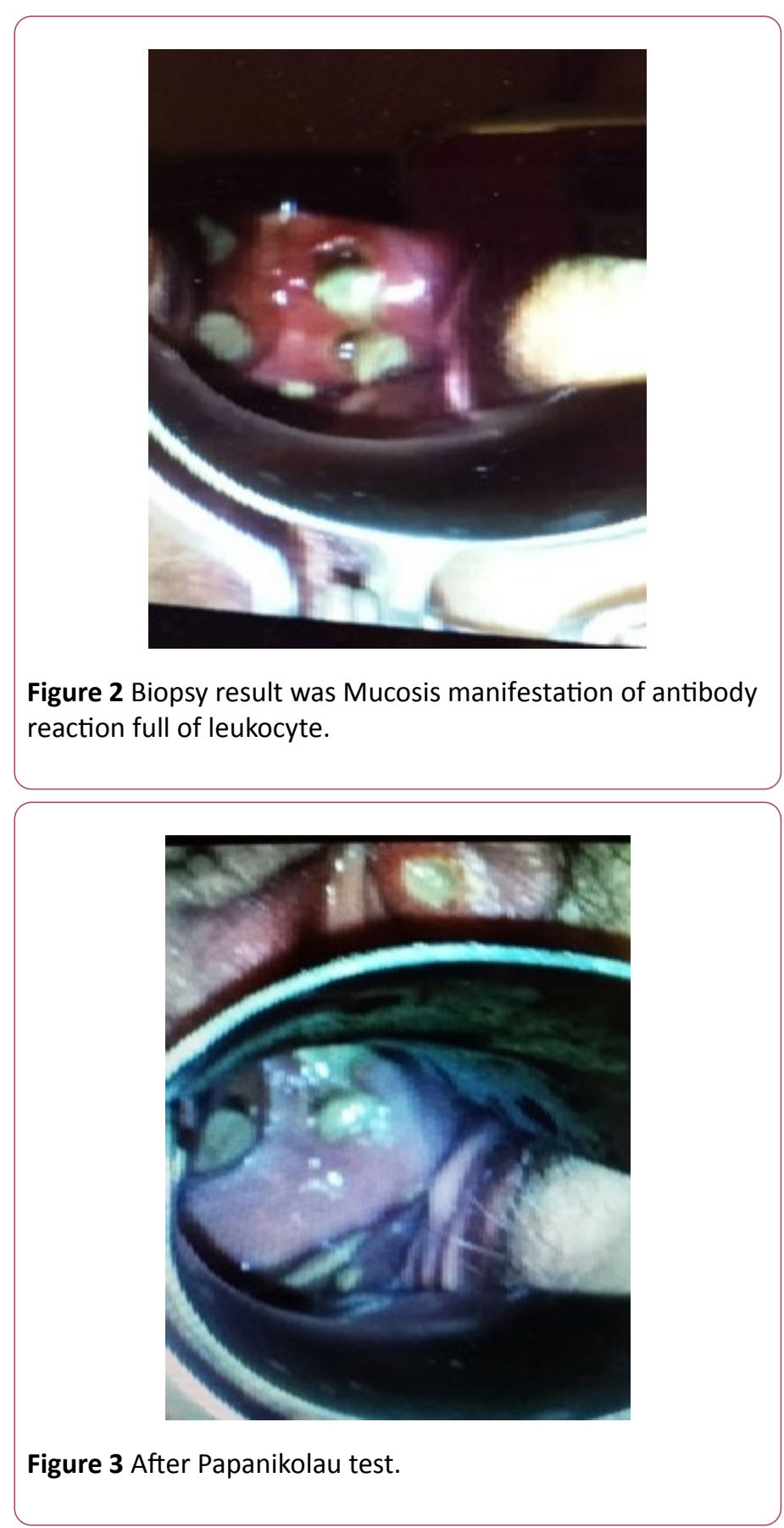




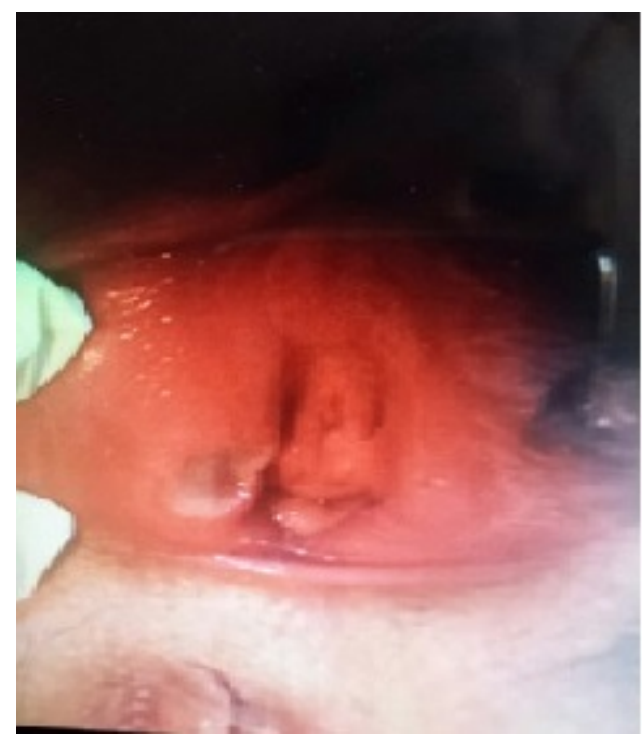

Figure 4 Before injecting dg "Morbus Behcet".

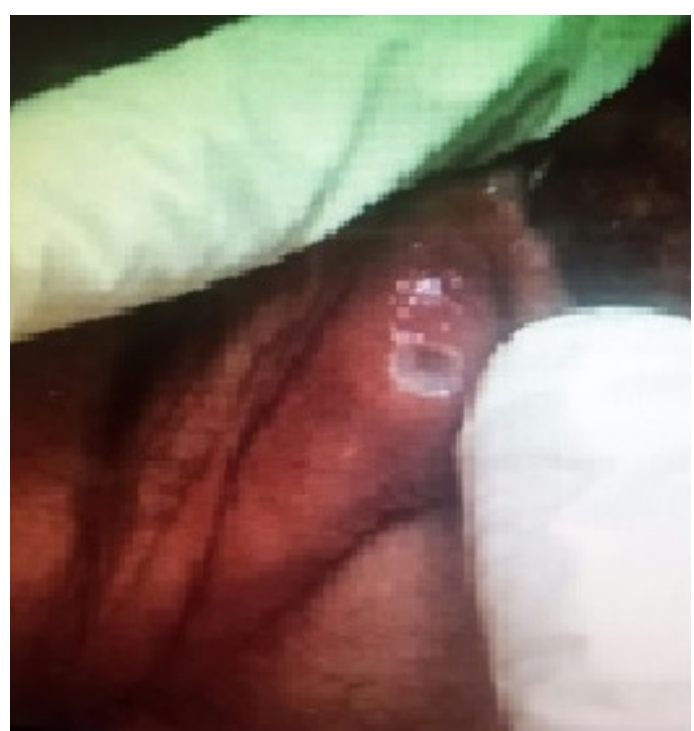

Figure 5 Status was found normal After injecting dg "Morbus Behcet". 